\title{
COMMENTARY/
}

\section{HAPHAZARD MEASURES: CHOLERA OR CHLORINATION?}

I

lived in the rain of black soot that fell on Pittsburgh throughout World War II. I lived for several years in a house where the drinking water tasted of kerosene from the oil well above the spring. I have worked with asbestos, PCBs (gallons, not parts per million), benzene, and assorted other poisons. I suspect there is 'conclusive data' proving that I should have died many years ago. I see things improving and it makes me very skeptical of claims that the sky is falling."

Andrew Dequasie's The Green Flame, published by the American Chemical Society, is an extraordinary book. The Raymond Chandler of chemical engineering, Dequasic has penned a racy, robust, often exciting, sometimes cynical account of the adventure that began in 1953 when he enlisted in a U.S. government project to develop boronbased super fuels for the army's Hermes Project. Not a critique of classificd research and close-run dangers, as suggested by the dust jacket, this is rather an affectionate, full-bodied memoir of a life compounded of bangs and leaks, fights with squirt guns, and fun with the girls. Safety officers do not loom large. Indeed, they hardly loom at all.

From my own, admittedly less colorful, experience of the chemical industry, I feel some empathy with Andrew Dequasie's questioning of our new timorousness towards hazardous living. Shortly after he plunged into the maelstrom of boron fuels, I went to work as a student at ICI's massive Billingham site in the north of England. A vivid memory from that time is of the daily dilemma of whether to consume one's lunchtime sandwiches on a bench within the ammonical effluvia from the ammonia plant or to brave the much lower $\mathrm{pH}$ surrounding the nitric acid works. The hazards of the latter were illustrated for all to see by an old, abandoned car that was visibly disintegrating nearby. Yet no one seemed to be concerned or to suffer any harm.

By today's standards, some of the industrial and laboratory practices of yesteryear certainly seem cavalicr. We have progressed. Accidents have bcen prevented, lives saved. But have we gone too far? Consider the task of moving a Winchester of sulphuric acid across the room from one bench to another. Do you stuff thick rubber gloves on your hands, reducing their coefficient of friction accordingly, and then swing the cargo in a cumbersome wicker basket? Or is it sounder and quicker to carry the bottle carefully with hands that are more sure and sensitive because they are bare? Does the physical awkwardness of much safety equipment, and the associated sense of security and remoteness from danger, argue for total nudity in the lab?

A grander question is whether the capacity to measure vanishingly tiny quantities of conjecturally harmful substances has distorted our thinking about chemical and biological hazards. From this perspective, the wave of cholera that is now sprcading in Latin America is surely an allegory of our time. In one sense, the outbreak is simply the latest chapter in the seventh pandemic of cholera that began in Indonesia some years ago and has since moved onwards through Africa and Asia. The bacterium seems to have arrived in Peru when a Chinese vessel released contaminated bilge water in to I ima harbour, from whence it passed into fish and seafood. But as Chris Anderson reported in Nature (354: 255, 1992), Vibrio cholerae was greatly helped on its way by the decision of Peruvian officials to suspend the routine chlorination of much of their country's drinking water. The reason for that, in turn, was the remote and unproven hazard to public health posed by chemicals that are formed when chlorine reacts with humic substances in water.

Now, it would be foolish to deny the concern that has been growing since 1974 with the discovery that not only distastcful chlorophenols but also potentially hazardous substances such as chloroform are occasionally produced during water treatment. Since then, several laboratories, including the Water Research Centre at Medmenham in the U.K., have identified a number of mutagens that result from the chlorination of humic acids in drinking water. We still know little about these chemicals, the mechanisms by which they are synthesised, or the relevance to human health of substances, shown to be mutagenic in in vitro tests, that occur in water in trace quantitics. Although any substantial danger might have been expected to emerge during past decades of worldwide water chlorination, there may still be small yet tangible hazards. Authorities such as the U.S. Environmental Protection Agency have, accordingly, laid down permissible limits for one of the groups of suspect compounds in drinking water, the trihalomethanes.

But the danger posed by a vilc and deadly disease such as cholera is on an altogether different scale. The most recent figures show that 250,000 people have been infected so far in the Iatin and Central American outbreak, and that 3000 victims have already died. We have, it seems, gotten our priorities hopclessly wrong. And the folly does not stop there. This month's Letters in Applied Microbiology (14: 51, 1992) records the fact that when this outbreak began, companies in South America sought advice from Unilever's research laboratory at Colworth in the U.K. about appropriatc hygicne measures. Unilever scientists were surprised to find that information about the sensitivity of $V$. cholerae to many disinfectants now in routine use was simply not available. Strains of this organism are not included in any presentday standard disinfectant tests in Europe or the U.S.A.

Thanks to Unilever, those data are now available. Fortunately, they are reassuring. But what on earth are we doing, fretting about measuring conjectural hazards on the margins of statistical significance, while neglecting the far less sophisticated science and technology through which really formidable dangers can be overcome?

Perhaps Andrew Dequasie has a point after all. /// 